\title{
Potassium ion channels in retinal ganglion cells (Review)
}

\author{
YI-SHENG ZHONG $^{1 *}$, JING WANG ${ }^{1 *}$,WANG-MIN LIU ${ }^{2}$ and YI-HUA ZHU $^{3}$ \\ ${ }^{1}$ Department of Ophthalmology, Ruijin Hospital Affiliated Medical School, Shanghai Jiaotong University, Shanghai 200025; \\ ${ }^{2}$ Hubei Provincial Center for Disease Control and Prevention, Wuhan, Hubei 430079; ${ }^{3}$ Department of Ophthalmology, \\ First Affiliated Hospital of Fujian Medical University, Fuzhou, Fujian 350005, P.R. China
}

Received January 15, 2013; Accepted May 22, 2013

DOI: $10.3892 / \mathrm{mmr} .2013 .1508$

\begin{abstract}
Retinal ganglion cells (RGCs) consolidate visual processing and constitute the last step prior to the transmission of signals to higher brain centers. RGC death is a major cause of visual impairment in optic neuropathies, including glaucoma, age-related macular degeneration, diabetic retinopathy, uveoretinitis and vitreoretinopathy. Discharge patterns of RGCs are primarily determined by the presence of ion channels. As the most diverse group of ion channels, potassium $\left(\mathrm{K}^{+}\right)$channels play key roles in modulating the electrical properties of RGCs. Biochemical, molecular and pharmacological studies have identified a number of $\mathrm{K}^{+}$channels in RGCs, including inwardly rectifying $\mathrm{K}^{+}\left(\mathrm{K}_{\mathrm{ir}}\right)$, ATP-sensitive $\mathrm{K}^{+}\left(\mathrm{K}_{\text {ATP }}\right)$, tandem-pore domain $\mathrm{K}^{+}$(TASK), voltage-gated $\mathrm{K}^{+}$ $\left(\mathrm{K}_{\mathrm{v}}\right)$, ether-à-go-go $(\mathrm{Eag})$ and $\mathrm{Ca}^{2+}$-activated $\mathrm{K}^{+}\left(\mathrm{K}_{\mathrm{Ca}}\right)$ channels. $\mathrm{K}_{\mathrm{ir}}$ channels are important in the maintenance of the resting membrane potential and controlling RGC excitability. $\mathrm{K}_{\mathrm{ATP}}$ channels are involved in RGC survival and neuroprotection. TASK channels are hypothesized to contribute to the regulation of resting membrane potentials and firing patterns of RGCs. $K_{v}$ channels are important regulators of cellular excitability, functioning to modulate the amplitude, duration and frequency of action potentials and subthreshold depolarizations, and are also important in RGC development and protection. Eag channels may contribute to dendritic repolarization during excitatory postsynaptic potentials and to the attenuation of the back propagation of action potentials. $\mathrm{K}_{\mathrm{Ca}}$ channels have been observed to contribute to repetitive firing
\end{abstract}

Correspondence to: Professor Wang-Min Liu, Hubei Provincial Center for Disease Control and Prevention, Building 13, 6 North Zhuodaoquan Road, Wuhan, Hubei 430079, P.R. China

E-mail:1wm662006@126.com

Professor Yi-Hua Zhu, Department of Ophthalmology, First Affiliated Hospital of Fujian Medical University, Building 1, 20 Chazhong Road Fuzhou, Fujian 350005, P.R. China

E-mail: zhuyihua889@hotmail.com

*Contributed equally

Key words: retinal ganglion cells, potassium ion channels, electrical property, neuroprotection in RGCs. Considering these important roles of $\mathrm{K}^{+}$channels in RGCs, the study of $\mathrm{K}^{+}$channels may be beneficial in elucidating the pathophysiology of RGCs and exploring novel RGC protection strategies.

\section{Contents}

\section{Introduction}

2. Classification of $\mathrm{K}^{+}$channels

3. Expression of $\mathrm{K}^{+}$channels in RGCs

4. Effects of $\mathrm{K}^{+}$channels on RGCs

5. $\mathrm{K}_{\text {ir }}$ channels

6. $\mathrm{K}_{\mathrm{ATP}}$ channels

7. TASK channels

8. $\mathrm{K}_{\mathrm{v}}$ channels

9. Eag channels

10. $\mathrm{K}_{\mathrm{Ca}}$ channels

11. Conclusions

\section{Introduction}

The retina originates in the neuroectodermal region and is derived from the anterior neural tube; thus, it is considered to be part of the central nervous system. The mature mammalian retina is classically divided into ten layers, which order from the inside to outside; the inner limiting membrane, nerve fiber layer, ganglion cell layer, inner plexiform layer, inner nuclear layer, outer plexiform layer, outer nuclear layer, external limiting membrane, photoreceptor layer and retinal pigment epithelium. The retina contains neuronal elements identified as photoreceptors and horizontal, bipolar and amacrine cells and retinal ganglion cells (RGCs) $(1,2)$. Comprising $~ 1 \%$ of all retinal cells, RGCs are the final output neurons of the retina (3). RGCs receive synaptic inputs from bipolar, amacrine and interplexiform cells, as well as from gap junctions. Their axons cross the retina and exit the eye via the optic disk, where they form the optic nerve, relaying information to the visual centers of the brain. Information received at the retinal level is conveyed to visual centers via discharge patterns of RGCs. Thus, the intrinsic membrane properties of RGCs are crucial in determining the methods by which visual information is transmitted to the brain (4). Discharge patterns of RGCs are primarily determined by the presence of ion channels, including sodium $\left(\mathrm{Na}^{+}\right)$and potassium $\left(\mathrm{K}^{+}\right)$ion channels. Of 
these ion channels, $\mathrm{K}^{+}$channels are important in RGC development, neurite outgrowth, axon guidance and action potential and repetitive firing regulation $(5,6)$.

A number of eye diseases, including glaucoma, ischemic optic neuropathy, retinal degeneration and trauma, may cause injury or the death of RGCs, and subsequently permanent visual dysfunction. The study of ion channels, particularly $\mathrm{K}^{+}$channels in RGCs, may be beneficial in elucidating the pathophysiology of RGCs and exploring novel RGC protection strategies. In the past three decades, there has been considerable progression in research on the function of $\mathrm{K}^{+}$channels in $\operatorname{RGCs}(7,8)$. The aim of the current review was to summarize the roles of $\mathrm{K}^{+}$channels in RGC development, neurite outgrowth, axon guidance and the modulation of electrical properties.

\section{Classification of $\mathrm{K}^{+}$channels}

There are several types of $\mathrm{K}^{+}$channels, including voltage-gated $\mathrm{K}^{+}\left(\mathrm{K}_{\mathrm{v}}\right), \mathrm{Ca}^{2+}$-activated $\mathrm{K}^{+}\left(\mathrm{K}_{\mathrm{Ca}}\right)$, inward-rectifier $\mathrm{K}^{+}\left(\mathrm{K}_{\mathrm{ir}}\right)$, tandem-pore domain $\mathrm{K}^{+}$(TASK; also named 'leak' $\mathrm{K}^{+}$) and ATP-sensitive $\mathrm{K}^{+}\left(\mathrm{K}_{\mathrm{ATP}}\right)$ channels $(7,8) . \mathrm{K}^{+}$channels are classified into three groups based on their predicted membrane topology; those with two, four and six transmembrane domains (TMDs; Fig 1). The first group, consisting of two TMDs, comprises $\mathrm{K}_{\mathrm{ir}}$ channels. The second group, consisting of four TMDs, comprises 'leak' $\mathrm{K}^{+}$channels (known as two-pore channels) and the third group with six TMDs comprises $\mathrm{K}_{v}$ and $\mathrm{K}_{\mathrm{Ca}}$ channels. Each of these groups is divided into families, which are further divided into subfamilies, the majority of which have several closely related members (8).

The first group has a predicted membrane topology of two TMDs (M1-M2) and a pore (P) domain; this group includes $\mathrm{K}_{\mathrm{ir}}$ and $\mathrm{K}_{\mathrm{ATP}}$ channels. Currently, seven subfamilies $\left(\mathrm{K}_{\mathrm{ir}} 1-7\right)$ have been identified, the majority of which form $\mathrm{K}^{+}$channels with varying degrees of inward rectification when expressed in heterologous expression systems (8).

The second group contains four putative TMDs (M1-4) and two P domains (P1 and 2) $(9,10)$ and are referred to as TASK channels. There are currently five members in this family (mechano-gated TREK, alkaline-activated TALK, calcium-activated TWIK, acid-inhibited TASK and halothane-inhibited THIK channels; Fig 1) (11-13), however, there is a possibility of new members being cloned in the future. The current responds to changes in the extracellular $\mathrm{K}^{+}$concentration, as described by the Goldman-Hodgkin-Katz equation, thus these channels are also referred to as 'leak' $\mathrm{K}^{+}$channels (9). A number of these channels may be extensively modulated by specific factors (e.g., arachidonic acid or pH) (14).

The third group contains six TMDs (S1-S6) with a conserved P (pore or H5) domain. When expressed in heterologous expression systems, $\mathrm{K}_{\mathrm{v}}$ and/or $\mathrm{K}_{\mathrm{Ca}}$ channels are formed. This group contains the $\mathrm{K}_{\mathrm{v}}$ channel family (with eight subfamilies, $\mathrm{K}_{\mathrm{v}} 1-6,8$ and 9), as well as members of the ether-à-go-go (Eag) and $\mathrm{K}_{\mathrm{Ca}}$ channel families (8).

\section{Expression of $\mathrm{K}^{+}$channels in RGCs}

Biochemical, molecular and pharmacological studies have identified numerous types of $\mathrm{K}^{+}$channels in RGCs, including $\mathrm{K}_{\mathrm{ir}}(15-17), \mathrm{K}_{\text {ATP }}(18)$, TASK (19), $\mathrm{K}_{\mathrm{v}}(6,15,20)$, Eag (21) and $\mathrm{K}_{\mathrm{Ca}}$ channels (Table I) $(22,23)$. Various subtypes of $\mathrm{K}_{\mathrm{ir}}$ channels have been confirmed to be expressed in RGCs in Xenopus laevis $(15)$ and rats $(16,17,22)$. Specific subunits of $\mathrm{K}_{\mathrm{v}}$ channels have been observed to be expressed in RGCs in Xenopus laevis $(6,15,24,25)$, goldfish (26), trout (27), mice $(28-30,31)$, rats $(20,32,33)$ and cats $(34)$. Eag1 and Eag2 have been reported to be expressed in RGCs in rats (21) and cattle (35). Large-conductance $\mathrm{K}_{\mathrm{Ca}}$ channels $\left(\mathrm{BK}_{\mathrm{Ca}}\right)$ and small-conductance $\mathrm{K}_{\mathrm{Ca}}$ channels $\left(\mathrm{SK}_{\mathrm{Ca}}\right)$ have been identified to express RGCs in ferrets (36), trout (27), mice (37) and rats $(22,23)$. Various subunits of $\mathrm{K}^{+}$channels are expressed in RGCs with distinct subcellular localization. Chen et al (16) previously reported that $\mathrm{K}_{\mathrm{ir}} 1.1$ was mainly expressed in the axons of RGCs, and $\mathrm{K}_{\mathrm{ir}} 2.1$ and $\mathrm{K}_{\mathrm{ir}} 2.3$ were present in the somata of RGCs. Staining methods demonstrated that $\mathrm{K}_{\mathrm{ir}} 3.1$ was primarily present in an endoplasmic reticulum-like structure and $\mathrm{K}_{\mathrm{ir}} 3.2$ was expressed in the cytoplasm and the cytomembrane of somata, dendrites and axons of RGCs. Faint, sparse labeling for $\mathrm{K}_{\mathrm{ir}} 3.3$ was observed in the cytomembrane. Tian et al (17) reported marked staining of $\mathrm{K}_{\mathrm{ir}} 2.1$ in the cytoplasm and staining for $\mathrm{K}_{\mathrm{ir}} 1.1,2.3,3.1,3.2,3.3$ and 4.2 was predominantly observed on the cell membrane. Concentrated $\mathrm{K}_{\mathrm{v}} 1.1$ and $\mathrm{K}_{\mathrm{v}} 1.3$ staining was present in RGC somata, while $\mathrm{K}_{\mathrm{v}} 1.2$ distribution was restricted, with intense staining in $\mathrm{RGC}$ axon fascicles $(20,29)$. Jow and Jeng (21) observed the expression of Eag1 and Eag2 in the somata of rat RGCs.

\section{Effects of $\mathrm{K}^{+}$channels on RGCs}

RGCs function as output neurons in the retina, encoding visual signals by producing spikes with characteristic spatial and temporal patterns. The encoded signals are relayed to visual centers via RGC axons. As the most diverse group of ion channels, $\mathrm{K}^{+}$channels play a key role in modulating the electrical properties of neurons $(5,6)$.

\section{5. $K_{\text {ir }}$ channels}

$\mathrm{K}_{\mathrm{ir}}$ channels are characterized by inward rectification, which allows more current to flow inward than outward via the channels (38). These channels are important for regulating neuronal signaling and membrane excitability (16,39-41). $\mathrm{K}_{\mathrm{ir}}$ channels are important in the maintenance of resting membrane potentials, thereby controlling the excitability of neurons (42). $\mathrm{K}_{\mathrm{ir}}$ channels are characterized by an increasing conductance under hyperpolarization and a decreasing conductance under depolarization (43). There are seven $\mathrm{K}_{\mathrm{ir}}$ subfamilies $\left(\mathrm{K}_{\mathrm{ir}} 1-7\right)(44)$, including ATP-regulated $\left(\mathrm{K}_{\mathrm{ir}} 1\right)$, classical $\left(\mathrm{K}_{\mathrm{ir}} 2\right)$ and $\mathrm{G}$-protein-coupled $\left(\mathrm{K}_{\mathrm{ir}} 3\right.$; GIRK). These subfamilies have varying properties and kinetics, mediating distinct physiological functions (45). It has previously been reported that GIRK channels containing $\mathrm{K}_{\mathrm{ir}} 3.2$ and 3.3 subunits mediate the hyperpolarization and decrease in the firing rate of rat locus coeruleus neurons caused by acute opioid administration (46). Activation of $\mathrm{K}_{\mathrm{ir}}$ channels serves as an underlying mechanism for improved RGC survival (43). Adenosine-induced hyperpolarization of RGCs is produced via the activation of $A_{1}$ receptors, initiating a signaling cascade that activates GIRK and $\mathrm{SK}_{\mathrm{Ca}}$ channels. This represents a novel mechanism of adenosine-mediated neuromodulation that may 


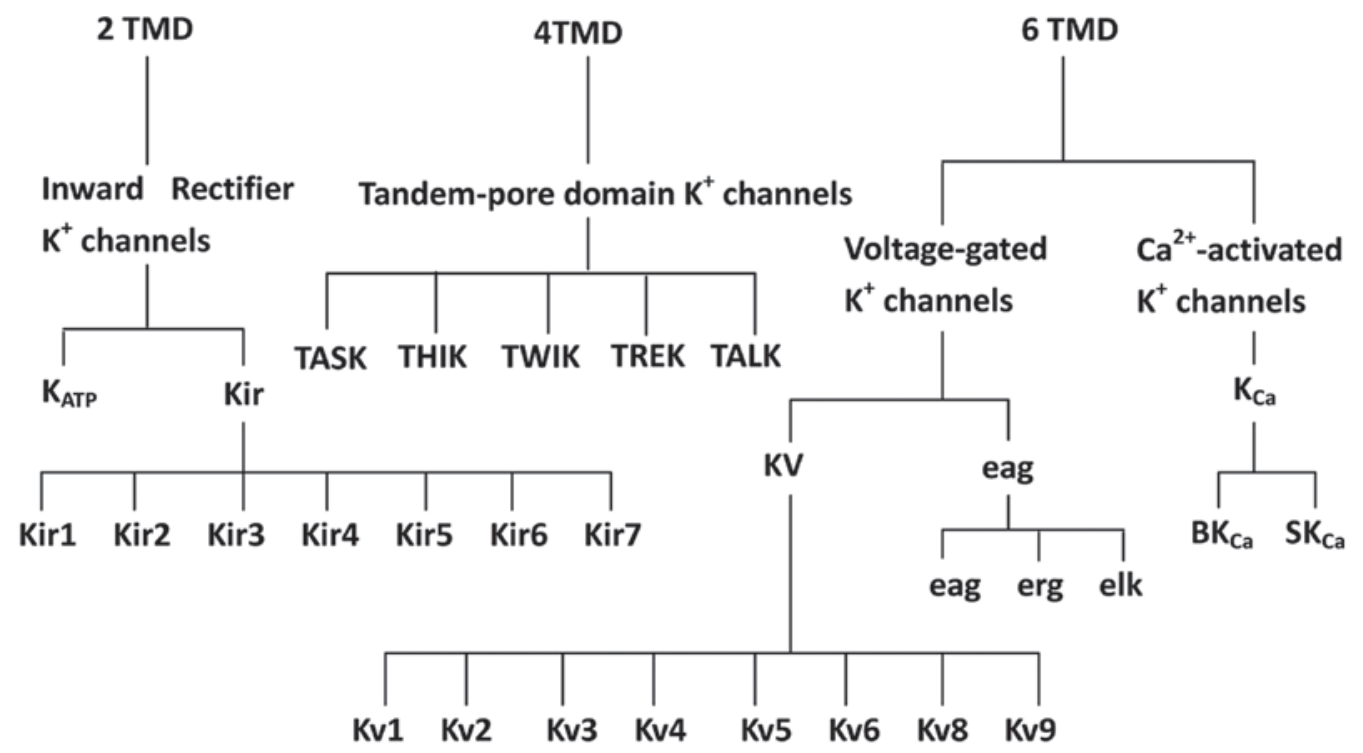

Figure 1. Classification of potassium ion channels. TMD, transmebrane domain; $\mathrm{K}_{\mathrm{ATP}}$, ATP-sensitive $\mathrm{K}^{+}$channel; Kir, inward-rectifier channel; TASK, tandempore domain $\mathrm{K}^{+}$channel; $\mathrm{KV}$, voltage-gated $\mathrm{K}^{+}$channel; $\mathrm{EAG}$, ether-á-go-go channel; $\mathrm{K}_{\mathrm{Ca}}, \mathrm{Ca}^{2+}$-activated channel; $\mathrm{BK}_{\mathrm{Ca}}$, large conductance $\mathrm{K}_{\mathrm{Ca}}$ channel; $\mathrm{SK}_{\mathrm{Ca}}$, small conductance $\mathrm{K}_{\mathrm{Ca}}$ channel.

contribute to the regulation of RGC activity (22). Flupirtine, a drug approved for patients suffering from chronic pain, may protect RGCs from degeneration in a non-inflammatory animal model of optic nerve transection. It has been verified through patch-clamp studies that the activation of $\mathrm{K}_{\mathrm{ir}}$ channels is involved in flupirtine-mediated neuroprotection (47).

\section{6. $\mathrm{K}_{\mathrm{ATP}}$ channels}

$\mathrm{K}_{\text {ATP }}$ channels belong to the family of $\mathrm{K}_{\mathrm{ir}}$ channels, and are composed of pore-forming units and a sulfonylurea binding site (48). These channels are located in the plasma membrane, as well as in the mitochondrial inner membranes $(43,49,50)$. Mitochondria supply energy to the cell via the synthesis of ATP. Respiring mitochondria transport $\mathrm{H}^{+}$into the cytoplasm, forming a transmembrane potential and $\mathrm{pH}$ gradient at the mitochondrial membrane. An influx of $\mathrm{K}^{+}$, due to the opening of mitochondrial $\mathrm{K}_{\mathrm{ATP}}$ channels, decreases the electrical gradient, but not the $\mathrm{pH}$ gradient, at the mitochondrial membrane. Consequently, mitochondria no longer have to maintain two gradients and therefore become more resistant to stress by conserving energy $(48,51)$. This indicates that $\mathrm{K}_{\text {ATP }}$ channels may be involved in RGC survival and neuroprotection. A number of studies have shown that $\mathrm{K}_{\mathrm{ATP}}$ channels are important in enhancing retinal resistance against ischemic insult $(18,52,53)$. Retinal ischemic injury induces retinal neuron cell death by excitotoxicity. In excitotoxic injury, increased glutamate causes the continuous opening of NMDA or kainate channels, damaging the retinal ion balance. The disturbed ionic environment is deleterious to retinal neurons and leads to cell death. ATP depletion leads to an opening of plasmalemmal channels, which hyperpolarizes the cell membrane in states of energy deficiency or ischemia (54). Yamauchi et al (52) previously reported that the opening of mitochondrial $\mathrm{K}_{\text {ATP }}$ channels may inhibit glutamate. The opening of $\mathrm{K}^{+}$channels induces the reduction of $\mathrm{K}^{+}$ion levels in the cytoplasm, which is accompanied by an increase in ischemic tolerance, mimicking ischemic preconditioning (55). This has been hypothesized to function in a similar manner to the way that low levels of $\mathrm{K}^{+}$ions inhibit or delay neuronal cell toxicity by $\mathrm{Ca}^{2+}$ influx in excitotoxicity (56). A number of potent $\mathrm{K}_{\text {АTP }}$-channel openers, including KR-31378 and gabapentin-lactam, exhibit RGC neuroprotection by regulating ion balance during excitotoxicity $(56,57) . \mathrm{K}_{\text {ATP }}$ channel agonists may prevent ischemia-induced expression of the immediate early genes, c-fos and c-jun (58). In addition, $\mathrm{K}_{\mathrm{ATP}}$ channels are essential for cerebral ischemic preconditioning (59-61). Early ischemic preconditioning has been demonstrated in the rat retina, and $\mathrm{K}_{\text {ATP }}$ channel openers mimic the effect of ischemic preconditioning (59). The activation of $\mathrm{K}_{\text {ATP }}$ channels following a sublethal ischemic stimulus may involve adenosine/adenosine receptors, as $\mathrm{K}_{\text {ATP }}$ channels are localized in close proximity to adenosine $A_{1}$ receptors (62). A release of endogenous adenosine from the retina following $\mathrm{K}^{+}$depolarization or ischemic insult has been reported $(63,64)$. It is therefore conceivable that adenosine formed from the breakdown of ATP may be released during the initial ischemia and indirectly activates $\mathrm{K}_{\text {ATP }}$ channels via the G-protein pathway following binding to the adenosine $A_{1}$ receptor (65). Sakamoto et al (53) observed that the stimulation of adenosine receptors, opening of $\mathrm{K}_{\text {ATP }}$ channels and activation of protein kinase $\mathrm{C}$ may be involved in the underlying protective mechanisms of early ischemic preconditioning.

\section{TASK channels}

TASK channels belong to the four putative TMD and two pore domain channels (13). These channels are divided into three subtypes, TASK-1, -2 and -3 . TASK channels are distinguished from other family members of $\mathrm{K}^{+}$channels due 
Table I. Potassium ion channels in retinal ganglion cells.

\begin{tabular}{|c|c|c|c|}
\hline Classes of $\mathrm{K}^{+}$channel & $\mathrm{K}^{+}$channel & Species & Reference \\
\hline \multirow[t]{10}{*}{ Inward-rectifier $\mathrm{K}^{+}$channels } & $\mathrm{K}_{\mathrm{ir}} 1.1$ & Rat & 16,17 \\
\hline & $\mathrm{K}_{\mathrm{ir}} 2.1$ & Xenopus laevis & 15 \\
\hline & & Rat & 16,17 \\
\hline & $\mathrm{K}_{\mathrm{ir}} 2.3$ & Rat & 16,17 \\
\hline & $\mathrm{K}_{\mathrm{ir}} 3(\mathrm{GIRK})$ & Rat & 22 \\
\hline & $\mathrm{K}_{\mathrm{ir}} 3.1$ & Rat & 16,17 \\
\hline & $\mathrm{K}_{\mathrm{ir}} 3.2$ & Rat & 16,17 \\
\hline & $\mathrm{K}_{\mathrm{ir}} 3.3$ & Rat & 16,17 \\
\hline & $\mathrm{K}_{\mathrm{ir}} 4.2$ & Rat & 17 \\
\hline & $\mathrm{K}_{\mathrm{ATP}}$ & Rat & 18 \\
\hline Tandem-pore domain $\mathrm{K}^{+}$channels & TASK-2 & Rat & 19 \\
\hline \multirow[t]{24}{*}{ Voltage-gated $\mathrm{K}^{+}$channels } & $\mathrm{K}_{\mathrm{v}}$ & Mouse & 28 \\
\hline & & Cat & 33 \\
\hline & $\mathrm{K}_{\mathrm{v}} 1.1$ & Xenopus laevis & 15 \\
\hline & & Rat & 20,31 \\
\hline & $\mathrm{K}_{\mathrm{v}} 1.2$ & Mouse & 29 \\
\hline & & Rat & 20 \\
\hline & $\mathrm{K}_{\mathrm{v}} 1.3$ & Xenopus laevis & 6 \\
\hline & & Mouse & 29 \\
\hline & & Rat & 20,31 \\
\hline & $\mathrm{K}_{\mathrm{v}} 1.4$ & Mouse & 29 \\
\hline & $\mathrm{K}_{\mathrm{v}} 1.5$ & Xenopus laevis & 6 \\
\hline & $\mathrm{K}_{\mathrm{v}} 2.1$ & Mouse & 29 \\
\hline & $\mathrm{K}_{\mathrm{v}} 3.1$ & Trout & 27 \\
\hline & & Rat & 32 \\
\hline & $\mathrm{K}_{\mathrm{v}} 3.2$ & Rat & 32 \\
\hline & $\mathrm{K}_{\mathrm{v}} 3.4$ & Xenopus laevis & 6 \\
\hline & $\mathrm{K}_{\mathrm{v}} 4.2$ & Goldfish & 26 \\
\hline & & Xenopus laevis & 6 \\
\hline & & Mouse & $29,30,37$ \\
\hline & $\mathrm{K}_{\mathrm{v}} 4.3$ & Xenopus laevis & 24,25 \\
\hline & Eag1 & Rat & 21 \\
\hline & & Bovine & 34 \\
\hline & Eag2 & Rat & 21 \\
\hline & & Bovine & 34 \\
\hline \multirow[t]{5}{*}{$\mathrm{Ca}^{2+}$-activated $\mathrm{K}^{+}$channels } & $\mathrm{SK}_{\mathrm{Ca}}$ & Ferret & 35 \\
\hline & & Rat & 22,23 \\
\hline & $\mathrm{BK}_{\mathrm{Ca}}$ & Ferret & 35 \\
\hline & & Trout & 27 \\
\hline & & Mouse & 36 \\
\hline
\end{tabular}

$\mathrm{K}_{\mathrm{ir}}$, inward-rectifier channel; GIRK, G-protein-coupled inwardly rectifying $\mathrm{K}^{+}$channel; $\mathrm{K}_{\text {ATP }}$, ATP-sensitive $\mathrm{K}^{+}$channel; TASK, tandem-pore domain $\mathrm{K}^{+}$channel; $\mathrm{K}_{\mathrm{V}}$, voltage-gated $\mathrm{K}^{+}$channel; Eag, ether-á-go-go channel; $\mathrm{BK}_{\mathrm{Ca}}$, large conductance $\mathrm{K}_{\mathrm{Ca}}$ channel; $\mathrm{SK}_{\mathrm{Ca}}$, small conductance $\mathrm{K}_{\mathrm{Ca}}$ channel.

to their sensitivities to changes in extracellular $\mathrm{pH}$. Although they have varying ranges of $\mathrm{pH}$ sensitivity, these channels are activated by extracellular alkaline $\mathrm{pH}$ and inhibited by acidic $\mathrm{pH}$ (19). TASK channels are not all voltage-gated and are resistant to conventional $\mathrm{K}^{+}$channel blockers. In addition, these channels have been hypothesized to contribute to the regulation of resting membrane potentials and firing patterns of neurons $(11,13)$. TASK-2 is expressed in RGCs, indicating that TASK-2 may be involved in the regulation of resting membrane potentials and firing patterns of RGCs. 


\section{8. $\mathrm{K}_{\mathrm{v}}$ channels}

$\mathrm{K}_{\mathrm{v}}$ channels contain eight potassium channel subfamilies $\left(\mathrm{K}_{\mathrm{v}} 1-6,8\right.$ and 9). All the electrically active $\mathrm{K}_{\mathrm{v}}$ channel subfamilies are represented in the adult rodent retina in spatially restricted patterns $(29,66,67)$. The coordinated expression of $\mathrm{K}_{\mathrm{v}}$ channels is of key importance for the maturation of membrane excitability and electrical signaling behavior in the retina. These channels determine the resting membrane potential of retinal neurons, particularly RGCs, modulating their intrinsic firing properties (68) and regulating neuronal differentiation processes (24). There are three aspects of the effect of $\mathrm{K}_{\mathrm{v}}$ channels on RGCs.

RGC electrical activity. $\mathrm{K}_{\mathrm{v}}$ currents are important regulators of cellular excitability, functioning to modulate the amplitude, duration and frequency of action potentials and subthreshold depolarizations. Altering $\mathrm{K}_{\mathrm{v}}$ channel function is useful for identifying the cellular processes that are regulated by excitability (69). $\mathrm{K}_{\mathrm{v}}$ channels carry outward currents that repolarize the membrane in response to action potentials or spontaneous depolarizations. Therefore, $\mathrm{K}_{\mathrm{v}}$ channels are critical for determining the shape of the action potential, the time course and extent of the hyperpolarization following a spike, return to resting potential, the delay to spike onset and in regulating repetitive firing $(5,44,70,71)$. In RGCs, $\mathrm{K}_{\mathrm{v}}$ channels exhibit a distinct subcellular localization pattern in the axon, thereby shaping the firing patterns of action potentials (72). $\mathrm{K}_{\mathrm{v}} 1.3$ channels produce a slowly inactivating current, whereas $\mathrm{K}_{\mathrm{v}} 1.1$ and 1.2 produce currents with fast or slow inactivation, depending on accessory molecules (73). Kuznetsov et al (33) observed that $\mathrm{K}_{\mathrm{v}} 3.1 / 3.2$ channels underlie the fast firing of rat RGCs and provide, at a given firing frequency, a 1.8-fold restriction of $\mathrm{Ca}^{2+}$ influx, which protects the cells from its cytotoxic action.

$R G C$ development. A number of studies have indicated that $\mathrm{K}_{\mathrm{v}}$ channels have important and varied roles in the development of neuronal cell types, and they have been implicated in numerous processes, including cell proliferation or differentiation, neurite outgrowth and axon guidance. Pollock et al (6) revealed that the retinal expression patterns of different $\mathrm{K}_{\mathrm{v}}$ channels have various roles in retinal development. $\mathrm{K}_{\mathrm{v}} 1.3$, 1.5, 3.4 and 4.2 channels became restricted to postmitotic retinal cells and/or synaptic layers, indicating additional roles for these channels in cell differentiation and synaptogenesis. The restricted and transient nature of $\mathrm{K}_{\mathrm{v}} 4.2$ protein expression in RGCs is particularly intriguing, as it implicates the $\mathrm{K}_{\mathrm{v}}$ channel in the differentiation of a specific RGC subtype. The presence of $\mathrm{K}_{\mathrm{v}} 1.3$ channels in axons indicates that they may be involved in the myelination of the optic nerve. $\mathrm{K}_{\mathrm{v}} 1.3,1.5$ and 3.4 subunits continue to be expressed by RGCs beyond the time the visual system first becomes functional, indicating that they are eventually involved in the regulation of electrical activity (6). It is proposed that these $\mathrm{K}_{\mathrm{v}}$ channels, through their control of membrane potential, regulate the downstream signaling of axon growth and guidance cues (74). Membrane excitability regulates the earliest differentiation of RGC dendritic arbors (15), while key regulators of membrane excitability are $K_{v}$ channels $(44,71)$. This indicates that $K_{v}$ may regulate the differentiation of RGC dendritic arbors.
McFarlane and Pollock (24) observed that RGCs and their growth cones express $\mathrm{K}_{\mathrm{v}}$ channels during progression to the midbrain target, the optic tectum. It was also observed that the blockade of $\mathrm{K}_{\mathrm{v}}$ channels using 4-aminopyridine, a $\mathrm{K}_{\mathrm{v}}$ channel blocker, inhibited RGC axon extension and caused the aberrant routing of numerous RGC fibers. Inhibiting $\mathrm{K}_{\mathrm{v}}$ channels affects the ability of RGC axons to extend in culture and causes extension and pathfinding defects of the axons in vivo. These observations indicate that $\mathrm{K}_{\mathrm{v}}$ channel activity regulates the guidance of growing axons of RGCs. Pollock et al (75) reported that the chemorepellent fibroblast growth factor-2 repulsed RGC growth cones in the presence of 4-aminopyridine, but not tetraethylammonium, indicating that tetraethylammonium- and 4-aminopyridine-sensitive $\mathrm{K}_{\mathrm{v}}$ channels differ in the manner by which they regulate the response of RGC axons to extension and guidance cues. Qu et al (30) noted that $\mathrm{K}_{\mathrm{v}} 4$.2-mediated currents were important for development in a subset of RGCs, particularly around postnatal day 10 as the bipolar cells mature. In addition, the majority of mouse and cat RGCs express $\mathrm{K}_{\mathrm{v}}$ currents soon after birth, before the cells have the ability to generate spontaneous action potentials $(28,33)$.

The regulation of intracellular calcium $\left(\left[\mathrm{Ca}^{2+}\right]_{\mathrm{i}}\right)$ appears to be a particularly attractive function for $\mathrm{K}_{\mathrm{v}}$ channels, since resting $\left[\mathrm{Ca}^{2+}\right]_{\mathrm{i}}$ and dynamic changes in $\left[\mathrm{Ca}^{2+}\right]_{\mathrm{i}}$ are important for regulating the response of the growth cone to extrinsic cues (76-78). In growth cones, $\mathrm{K}_{\mathrm{v}}$ channel activity may function to modulate $\left[\mathrm{Ca}^{2+}\right]_{\mathrm{i}}$ by regulating the membrane potential and opening voltage-gated $\mathrm{Ca}^{2+}$ channels. Maruoka et al (79) and Petrecca et al (80) observed that $\mathrm{K}_{\mathrm{v}} 1.5$ and 4.2 channels coimmunoprecipitated with the cytoskeletal components of $\alpha$-actinin- 2 and filamin, respectively, indicating the possibility of specific $\mathrm{K}_{\mathrm{v}}$ channels functioning directly or indirectly in the reorganization of the cytoskeleton in response to extrinsic cues.

$R G C$ protection. Apoptosis in several cell types is accompanied by increased $\mathrm{K}^{+}$currents, the depletion of cytoplasmic $\mathrm{K}^{+}$ and cell shrinkage (81-84). This 'apoptotic volume decrease' precedes mitochondrial depolarization, apoptosome formation and cell fragmentation, and is considered to be a triggering event (81-84). The volume decrease of apoptotic cells occurs through the channel- and transporter-mediated efflux of osmolytes, particularly $\mathrm{K}^{+}$and chloride ions. This ion efflux creates an osmotic gradient that draws water out of the cells (85-87). The decrease in cytoplasmic $\mathrm{K}^{+}$concentration may activate molecules in the apoptotic cascade. Consequently, one experimental strategy has been to target $\mathrm{K}^{+}$channels. An increasing number of studies support the hypothesis that $\mathrm{K}_{\mathrm{v}}$ channels are involved in the protection of RGCs. $\mathrm{K}_{\mathrm{v}} 1.1$ and $\mathrm{K}_{\mathrm{v}} 1.3$ channels contribute to cell-autonomous death of RGCs through various components of the apoptotic machinery (20). $\mathrm{K}_{\mathrm{v}} 1.1$ depletion increases the anti-apoptotic gene, Bcl-xL. By contrast $\mathrm{K}_{\mathrm{v}} 1.3$ depletion reduces the pro-apoptotic genes, caspase-3, caspase- 9 and $\mathrm{Bad}(20)$. It has been reported that $\mathrm{K}_{\mathrm{v}}$ contributions depend on their location. $\mathrm{K}_{\mathrm{v}} 1.1$ and 1.3 are highly expressed in RGC somata and have the greatest effect on cell survival, whereas the contribution of the predominantly axonal $\mathrm{K}_{\mathrm{v}} 1.2$ channel is limited (20). By contrast, $\mathrm{K}_{\mathrm{v}}$ channels are functionally linked to RGC degeneration indirectly via non-neuronal cells, most likely by blocking $\mathrm{K}_{\mathrm{v}} 1.3$ channels in microglia $(31,88-90)$. The 
$\mathrm{K}_{\mathrm{v}} 1.3$ channel is highly expressed in microglia and contributes to microglial activation and neurotoxicity (91). Utilizing the optic nerve transection model, Koeberle et al (32) reported the following observations: (i) Following optic nerve transection, intraocular injection of agitoxin-2, a potent blocker of $\mathrm{K}_{\mathrm{v}} 1.3$ channels, reduced microglial activation and the expression of several inflammatory genes in the damaged retina, which indicated that $\mathrm{K}_{\mathrm{v}}$ channels contribute to inflammation in the adult retina in vivo; (ii) the retinal expression of several growth factors was upregulated following axotomy. Intraocular injection of margatoxin, a blocker of $\mathrm{K}_{\mathrm{v}} 1.3$ channels, increased retinal b-FGF. By contrast, RGC-specific depletion of $\mathrm{K}_{\mathrm{v}} 1.3$ from RGCs decreased GDNF and b-FGF levels. Agitoxin-2 injection did not affect growth factor levels; (iii) injecting agitoxin-2 increased c-Fos, TGF $\beta$, IL-1 $\beta$, IL-1ra and TNF $\alpha$ beyond any effects of $\mathrm{K}_{\mathrm{v}} 1.1$ or $\mathrm{K}_{\mathrm{v}} 1.3$ channel knockdown in RGCs; and (iv) combining siRNA-mediated knockdown of $\mathrm{K}_{\mathrm{v}} 1.1$ or 1.3 with intraocular injection of agitoxin-2 or margatoxin provided increased RGC rescue, with up to $55 \%$ of RGCs surviving at day 14 following optic nerve transection (31). In addition, as the $\mathrm{K}_{\mathrm{v}} 1.3$ channel is important for the activation of $\mathrm{T}$ lymphocytes, it is also possible that this channel is involved in immune-mediated damage in the retina (92).

\section{Eag channels}

The Eag channel was the first reported member of the Eag family of voltage-gated $\mathrm{K}^{+}$channels (93). In mammals, two Eag channel subunit isoforms have been identified, Eag1 and Eag2, sharing $\sim 70 \%$ identity in amino acid sequence (94-96). Jow and Jeng (21) observed that Eag1 channels are localized at the dendrites and somata of RGCs, and Eag2 channels are localized at the somata of RGCs. Eag1 and Eag2 channels have also been identified to express RGCs in cattle (34). The widespread expression of Eag1 channels in the somatodendritic compartment indicates that these channels may contribute to dendritic repolarization during excitatory postsynaptic potentials and to the attenuation of the back propagation of action potentials. Thus, Eag1 channels are critical in regulating electrical coupling between dendrites and cell bodies in RGCs (21). In addition, Eag channels are involved in the formation of $\mathrm{I}_{\mathrm{Kx}}$ channels and may contribute to the dark current in the rod inner segment (34).

\section{0. $\mathrm{K}_{\mathrm{Ca}}$ channels}

Single channel studies have revealed several types of calcium-activated potassium channels, which may be divided into two distinct groups based on their pharmacological and biophysical properties, $\mathrm{BK}_{\mathrm{Ca}}$ and $\mathrm{SK}_{\mathrm{Ca}} \cdot \mathrm{BK}_{\mathrm{Ca}}$ channels, which may be blocked by charybdotoxin (CTX), have a high unitary conductance and exhibit sensitivity to voltage and submicromolar concentrations of CTX (97). The current passing through these channels has been implicated in action potential repolarization and fast hyperpolarization following the spike (98). By contrast, $\mathrm{SK}_{\mathrm{Ca}}$ channels have a markedly lower unitary conductance, are voltage- and CTX-insensitive and are activated by nanomolar concentrations of calcium (97). The current flowing through these channels is sensitive to apamin, a $\mathrm{SK}_{\mathrm{Ca}}$ channel blocker, and has been shown to underlie the slow after-hyperpolarization that is responsible for action potential frequency adaptation in a number of cells $(99,100)$. $\mathrm{K}_{\mathrm{Ca}}$ currents have been reported to be important in the regulation of neuronal activity. In particular, these currents have been shown to contribute towards the repolarizing phase of the action potential (98), control the repetitive discharge of spikes (101-103) and are involved in various forms of oscillatory membrane behavior (104).

$\mathrm{BK}_{\mathrm{Ca}}$ and $\mathrm{SK}_{\mathrm{Ca}}$ channels are located in RGCs $(3,35,105)$. $\mathrm{K}_{\mathrm{Ca}}$ channels contribute to repetitive firing in RGCs (105), and blocking $\mathrm{K}_{\mathrm{Ca}}$ channels has been shown to increase the current-evoked firing rate of RGCs in ferret retinas (35). Whole-cell recordings from isolated and intact RGCs revealed that conductances regulate the frequency of spike discharges in response to maintained depolarizations. Activation of these channels leads to an increase in the time to spike threshold and in the hyperpolarization following the spike, decreasing the rate of sustained discharges (35). Wang et al (106) revealed that apamin induced low-frequency bursts of a relatively long duration, a pattern similar to that observed in developing RGCs. By contrast, CTX induced high-frequency bursts of a short duration that were periodic; these observations indicate that the modulation of $\mathrm{K}_{\mathrm{Ca}}$ conductances provides an effective means for affecting the spontaneous discharge patterns of RGCs. In addition, firing patterns were evident following blockade of the small conductance and resembled the spontaneous discharges noted during development, indicating a possible link between the functional state of $\mathrm{K}_{\mathrm{Ca}}$ conductances and the spontaneous discharges manifested by immature RGCs (106). Utilizing patch-clamp recordings in mouse RGCs, Nemargut et al (37) observed that during dark adaptation, the blockage of $\mathrm{BK}_{\mathrm{Ca}}$ channels increased the spontaneous excitatory postsynaptic currents (EPSCs) and light-evoked on-EPSCs, while it decreased the light-evoked off-inhibitory postsynaptic currents (IPSCs). However, under light adaptation, it decreased the light-evoked on-EPSCs, the spontaneous IPSCs and the light-evoked on- and off-IPSCs. The blockage of $\mathrm{BK}_{\mathrm{Ca}}$ channels significantly altered the outputs of RGCs by changing their light-evoked responses into a bursting pattern and increasing the light-evoked depolarization of the membrane potentials, while it did not significantly change the peak firing rates of light-evoked responses (36). These observations indicate that $\mathrm{BK}_{\mathrm{Ca}}$ channels play various roles in mediating visual signals in the retina under different ambient light conditions.

\section{Conclusions}

The discharge patterns of RGCs are primarily determined by the presence of ion channels. As the most diverse group of ion channels, $\mathrm{K}^{+}$channels are key in modulating the electrical properties of RGCs. Biochemical, molecular and pharmacological studies have identified numerous types of $\mathrm{K}^{+}$channels in RGCs, including $\mathrm{K}_{\mathrm{ir}}, \mathrm{K}_{\mathrm{ATP}}$, TASK, $\mathrm{K}_{\mathrm{v}}$, Eag and $\mathrm{K}_{\mathrm{Ca}}$. $\mathrm{K}_{\mathrm{ir}}$ channels are important in maintaining the resting membrane potential and modulating RGC excitability. $\mathrm{K}_{\mathrm{ATP}}$ channels are involved in RGC survival and neuroprotection. TASK channels are considered to contribute to the regulation of resting membrane potentials and the firing patterns of RGCs. $\mathrm{K}_{\mathrm{v}}$ channels are important regulators of cellular excitability, functioning to modulate the amplitude, duration and frequency of action 
potentials and subthreshold depolarizations. $\mathrm{K}_{\mathrm{v}}$ channels are important in RGC development and protection. Eag channels may contribute to dendritic repolarization during excitatory postsynaptic potentials and to the attenuation of the back propagation of action potentials. $\mathrm{K}_{\mathrm{Ca}}$ channels have been observed to contribute to repetitive firing in RGCs. Considering these important roles of $\mathrm{K}^{+}$channels on RGCs, the study of $\mathrm{K}^{+}$channels may be conducive to elucidating the pathophysiology of RGCs and to explore new RGC protection strategies.

\section{Acknowledgements}

This study was funded by the Shanghai Leading Academic Discipline Project (no. S30205) and the Shanghai 'Science and Technology Innovation Action Plan' Basic Research Key Project (nos. 11JC1407700 and 11JC1407701).

\section{References}

1. Pycock CJ: Retinal neurotransmission. Surv Ophthalmol 29: $355-365,1985$.

2. Marquardt T and Gruss P: Generating neuronal diversity in the retina: one for nearly all. Trends Neurosci 25: 32-38, 2002.

3. Lipton SA and Tauck DL: Voltage-dependent conductances of solitary ganglion cells dissociated from the rat retina. J Physiol 385: 361-391, 1987.

4. Robinson DW and Chalupa LM: The intrinsic temporal properties of alpha and beta retinal ganglion cells are equivalent. Curr Biol 7: 366-374, 1997.

5. Augustine GJ: Regulation of transmitter release at the squid giant synapse by presynaptic delayed rectifier potassium current. J Physiol 431: 343-364, 1990.

6. Pollock NS, Ferguson SC and McFarlane S: Expression of voltage-dependent potassium channels in the developing visual system of Xenopus laevis. J Comp Neurol 452: 381-391, 2002.

7. Rudy B: Diversity and ubiquity of K channels. Neuroscience 25 : 729-749, 1988.

8. Coetzee WA, Amarillo Y, Chiu J, Chow A, Lau D, McCormack T, Moreno H, Nadal MS, Ozaita A, Pountney D, Saganich M, Vega-Saenz de Miera E and Rudy B: Molecular diversity of $\mathrm{K}^{+}$ channels. Ann NY Acad Sci 868: 233-285, 1999.

9. Goldstein SA, Wang KW, Ilan N and Pausch MH: Sequence and function of the two $\mathrm{P}$ domain potassium channels: implications of an emerging superfamily. J Mol Med (Berl) 76: 13-20, 1998

10. Lesage F, Guillemare E, Fink M, Duprat F, Lazdunski M, Romey $\mathrm{G}$ and Barhanin J: TWIK-1, a ubiquitous human weakly inward rectifying $\mathrm{K}^{+}$channel with a novel structure. EMBO J 15: 1004-1011, 1996 .

11. Honoré E: The neuronal background K2P channels: focus on TREK1. Nat Rev Neurosci 8: 251-261, 2007.

12. Mathie A: Neuronal two-pore-domain potassium channels and their regulation by $\mathrm{G}$ protein-coupled receptors. J Physiol 578: 377-385, 2007.

13. O'Connell AD, Morton MJ and Hunter M: Two-pore domain $\mathrm{K}^{+}$channels-molecular sensors. Biochim Biophys Acta 1566: $152-161,2002$

14. Fink M, Lesage F, Duprat F, Heurteaux C, Reyes R, Fosset M and Lazdunski M: A neuronal two $\mathrm{P}$ domain $\mathrm{K}^{+}$channel stimulated by arachidonic acid and polyunsaturated fatty acids. EMBO J 17 : 3297-3308, 1998.

15. Hocking JC, Pollock NS, Johnston J, Wilson RJ, Shankar A and McFarlane S: Neural activity and branching of embryonic retinal ganglion cell dendrites. Mech Dev 129: 125-135, 2012.

16. Chen L, Yu YC, Zhao JW and Yang XL: Inwardly rectifying potassium channels in rat retinal ganglion cells. Eur J Neurosci 20: 956-964, 2004

17. Tian M, Chen L, Xie JX, Yang XL and Zhao JW: Expression patterns of inwardly rectifying potassium channel subunits in rat retina. Neurosci Lett 345: 9-12, 2003.

18. Ettaiche M, Heurteaux C, Blondeau N, Borsotto M, Tinal N and Lazdunski M: ATP-sensitive potassium channels (K(ATP)) in retina: a key role for delayed ischemic tolerance. Brain Res 890: $118-129,2001$
19. Zhang XM, Zhong YM and Yang XL: TASK-2 is expressed in proximal neurons in the rat retina. Neuroreport 20: 946-950,2009.

20. Koeberle PD, Wang Y and Schlichter LC: Kv1.1 and Kv1.3 channels contribute to the degeneration of retinal ganglion cells after optic nerve transection in vivo. Cell Death Differ 17: 134-144, 2010.

21. Jow GM and Jeng CJ: Differential localization of rat Eag1 and Eag2 potassium channels in the retina. Neurosci Lett 431: 12-16, 2008.

22. Clark BD, Kurth-Nelson ZL and Newman EA: Adenosine-evoked hyperpolarization of retinal ganglion cells is mediated by G-protein-coupled inwardly rectifying $\mathrm{K}^{+}$and small conductance $\mathrm{Ca}^{2+}$-activated $\mathrm{K}^{+}$channel activation. J Neurosci 29: 11237-11245, 2009.

23. Klöcker N, Oliver D, Ruppersberg JP, Knaus HG and Fakler B: Developmental expression of the small-conductance $\mathrm{Ca}(2+)$-activated potassium channel SK2 in the rat retina. Mol Cell Neurosci 17: 514-520, 2001.

24. McFarlane S and Pollock NS: A role for voltage-gated potassium channels in the outgrowth of retinal axons in the developing visual system. J Neurosci 20: 1020-1029, 2000.

25. Lautermilch NJ and Spitzer NC: The KV4.3 Shal gene is developmentally upregulated in Xenopus embryos and encodes a potassium current modulated by arachidonic acid. Soc Neurosci Abstr 23: 1738, 1997.

26. Yazulla S and Studholme KM: Co-localization of Shaker A-type $\mathrm{K}^{+}$channel (Kv1.4) and AMPA-glutamate receptor (GluR4) immunoreactivities to dendrites of OFF-bipolar cells of goldfish retina. J Neurocytol 28: 63-73, 1999.

27. Henne $J$ and Jeserich G: Maturation of spiking activity in trout retinal ganglion cells coincides with upregulation of Kv3.1- and BK-related potassium channels. J Neurosci Res 75: 44-54, 2004.

28. Rörig B and Grantyn R: Ligand- and voltage-gated ion channels are expressed by embryonic mouse retinal neurones. Neuroreport 5: 1197-1200, 1994.

29. Pinto LH and Klumpp DJ: Localization of potassium channels in the retina. Prog Retin Eye Res 17: 207-230, 1998.

30. Qu J, Mulo I and Myhr KL: The development of Kv4.2 expression in the retina. Neurosci Lett 464: 209-213, 2009.

31. Klumpp DJ, Song EJ and Pinto LH: Identification and localization of $\mathrm{K}^{+}$channels in the mouse retina. Vis Neurosci 12: 1177-1190, 1995

32. Koeberle PD and Schlichter LC: Targeting K(V) channels rescues retinal ganglion cells in vivo directly and by reducing inflammation. Channels (Austin) 4: 337-346, 2010.

33. Kuznetsov KI, Grygorov OO, Maslov VY, Veselovsky NS and Fedulova SA: Kv3 channels modulate calcium signals induced by fast firing patterns in the rat retinal ganglion cells. Cell Calcium 52: 405-411, 2012.

34. Skaliora I, Robinson DW, Scobey RP and Chalupa LM: Properties of $\mathrm{K}^{+}$conductances in cat retinal ganglion cells during the period of activity-mediated refinements in retinofugal pathways. Eur J Neurosci 7: 1558-1568, 1995.

35. Frings S, Brüll N, Dzeja C, Angele A, Hagen V, Kaupp UB and Baumann A: Characterization of ether-à-go-go channels present in photoreceptors reveals similarity to IKx, a $\mathrm{K}^{+}$current in rod inner segments. J Gen Physiol 111: 583-599, 1998.

36. Wang GY, Robinson DW and Chalupa LM: Calcium-activated potassium conductances in retinal ganglion cells of the ferret. J Neurophysiol 79: 151-158, 1998.

37. Nemargut JP,Zhu J, Savoie BT and Wang GY: Differential effects of charybdotoxin on the activity of retinal ganglion cells in the dark- and light-adapted mouse retina. Vision Res 49: 388-397, 2009.

38. Isomoto $\mathrm{S}$, Kondo $\mathrm{C}$ and Kurachi Y: Inwardly rectifying potassium channels: their molecular heterogeneity and function. Jpn J Physiol 47: 11-39, 1997.

39. Nichols CG and Lopatin AN: Inward rectifier potassium channels. Annu Rev Physiol 59: 171-191, 1997.

40. Neusch C, Weishaupt JH and Bähr M: Kir channels in the CNS: emerging new roles and implications for neurological diseases. Cell Tissue Res 311: 131-138, 2003.

41. Tanaka S, Wu N, Hsaio CF, Turman J Jr and Chandler SH: Development of inward rectification and control of membrane excitability in mesencephalic v neurons. J Neurophysiol 89: 1288-1298, 2003.

42. Pongs O: Molecular biology of voltage-dependent potassium channels. Physiol Rev 72 (4 Suppl): S69-S88, 1992.

43. Kubo Y, Baldwin TJ, Jan YN and Jan LY: Primary structure and functional expression of a mouse inward rectifier potassium channel. Nature 362: 127-133, 1993. 
44. Jan LY and Jan YN: Voltage-gated and inwardly rectifying potassium channels. J Physiol 505: 267.b1-282, 1997.

45. Reimann $\mathrm{F}$ and Ashcroft FM: Inwardly rectifying potassium channels. Curr Opin Cell Biol 11: 503-508, 1999.

46. Torrecilla M, Marker CL, Cintora SC, Stoffel M, Williams JT and Wickman K: G-protein-gated potassium channels containing Kir3.2 and Kir3.3 subunits mediate the acute inhibitory effects of opioids on locus ceruleus neurons. J Neurosci 22: 4328-4334, 2002.

47. Sättler MB, Williams SK, Neusch C, Otto M, Pehlke JR, Bähr M and Diem R: Flupirtine as neuroprotective add-on therapy in autoimmune optic neuritis. Am J Pathol 173 1496-1507, 2008.

48. Szewczyk A and Marbán E: Mitochondria: a new target for K channel openers? Trends Pharmacol Sci 20: 157-161, 1999.

49. Inagaki N, Gonoi $T$, Clement JP 4th, Namba N, Inaza J, Gonzalez G, Aguilar-Bryan L, Seino $S$ and Bryan J: Reconstitution of IKATP: an inward rectifier subunit plus the sulfonylurea receptor. Science 270: 1166-1170, 1995.

50. Inagaki N, Inazawa J and Seino S: cDNA sequence, gene structure and chromosomal localization of the human ATP-sensitive potassium channel, uKATP-1, gene (KCNJ8). Genomics 30: 102-104, 1995.

51. Kicińska A, D bska G, Kunz W and Szewczyk A: Mitochondrial potassium and chloride channels. Acta Biochim Pol 47: 541-551, 2000.

52. Yamauchi T, Kashii S, Yasuyoshi H, Zhang S, Honda Y and Akaike A: Mitochondrial ATP-sensitive potassium channel: a novel site for neuroprotection. Invest Ophthalmol Vis Sci 44: 2750-2756, 2003.

53. Sakamoto K, Yonoki Y, Kuwagata M, Saito M, Nakahara T and Ishii K: Histological protection against ischemia-reperfusion injury by early ischemic preconditioning in rat retina. Brain Res 1015: 154-160, 2004.

54. Kersten JR, Gross GJ, Pagel PS and Warltier DC: Activation of adenosine triphosphate-regulated potassium channels: mediation of cellular and organ protection. Anesthesiology 88: 495-513, 1998

55. Rodrigo GC and Standen NB: ATP-sensitive potassium channels. Curr Pharm Des 11: 1915-1940, 2005.

56. Choi A, Choi JS, Yoon YJ, Kim KA and Joo CK: KR-31378, a potassium-channel opener, induces the protection of retinal ganglion cells in rat retinal ischemic models. J Pharmacol Sci 109: 511-517, 2009.

57. Pielen A, Kirsch M,Hofmann HD, Feuerstein TJ and Lagrèze WA Retinal ganglion cell survival is enhanced by gabapentin-lactam in vitro: evidence for involvement of mitochondrial KATP channels. Graefes Arch Clin Exp Ophthalmol 242: 240-244, 2004.

58. Heurteaux C, Bertaina V, Widmann $\mathrm{C}$ and Lazdunski $\mathrm{M}: \mathrm{K}^{+}$ channel openers prevent global ischemia-induced expression of c-fos, c-jun, heat shock protein and amyloid $\beta$-protein precursor genes and neuronal death in rat hippocampus. Proc Natl Acad Sci USA 90: 9431-9435, 1993.

59. Heurteaux C, Lauritzen I, Widmann $\mathrm{C}$ and Lazdunski $\mathrm{M}$ Essential role of adenosine, adenosine A1 receptors and ATP-sensitive $\mathrm{K}^{+}$channels in cerebral ischemic preconditioning. Proc Natl Acad Sci USA 92: 4666-4670, 1995.

60. Liu Y, Sato T, Seharaseyon J, Szewczyk A, O'Rourke B and Marbán E: Mitochondrial ATP-dependent potassium channels. Viable candidate effectors of ischemic preconditioning. Ann NY Acad Sci 874: 27-37, 1999.

61. Tanno M, Miura T, Tsuchida A, Miki T, Nishino Y, Ohnuma Y and Shimamoto K: Contribution of both the sarcolemmal $\mathrm{K}(\mathrm{ATP})$ and mitochondrial K(ATP) channels to infarct size limitation by K(ATP) channel openers: differences from preconditioning in the role of sarcolemmal K(ATP) channels. Naunyn Schmiedebergs Arch Pharmacol 364: 226-232, 2001

62. Kvanta A, Seregard S, Sejersen S, Kull B and Fredholm BB: Localization of adenosine receptor messenger RNAs in the rat eye. Exp Eye Res 65: 595-602, 1997

63. Roth S, Park SS, Sikorski CW, Osinski J, Chan R and Loomis K Concentrations of adenosine and its metabolites in the rat retina/choroid during reperfusion after ischemia. Curr Eye Res 16: 875-885, 1997.

64. Roth S, Rosenbaum PS, Osinski J, Park SS, Toledano AY, Li B and Moshfeghi AA: Ischemia induces significant changes in purine nucleoside concentration in the retina-choroid in rats. Exp Eye Res 65: 771-779, 1997.

65. Kurachi Y: G protein regulation of cardiac muscarinic potassium channel. Am J Physiol 269: C821-C830, 1995.
66. Serôdio P and Rudy B: Differential expression of Kv4 $\mathrm{K}^{+}$channel subunits mediating subthreshold transient $\mathrm{K}^{+}$(A-type) currents in rat brain. J Neurophysiol 79: 1081-1091, 1998.

67. Yazulla S and Studholme KM: Differential distribution of Shaker-like and Shab-like $\mathrm{K}^{+}$-channel subunits in goldfish retina and retinal bipolar cells. J Comp Neurol 396: 131-140, 1998.

68. Dantzker JL and Callaway EM: The development of local, layer-specific visual cortical axons in the absence of extrinsic influences and intrinsic activity. J Neurosci 18: 4145-4154, 1998.

69. Ribera AB and Spitzer NC: Developmental regulation of potassium channels and the impact on neuronal differentiation. Ion Channels 3: 1-38, 1992.

70. Jan LY and Jan YN: Cloned potassium channels from eukaryotes and prokaryotes. Annu Rev Neurosci 20: 91-123, 1997.

71. Wei A, Jegla T and Salkoff L: Eight potassium channel families revealed by the $C$. elegans genome project. Neuropharmacology 35: 805-829, 1996.

72. Van Wart A, Trimmer JS and Matthews G: Polarized distribution of ion channels within microdomains of the axon initial segment. J Comp Neurol 500: 339-352, 2007.

73. Grissmer S, Nguyen AN, Aiyar J, Hanson DC, Mather RJ, Gutman GA, Karmilowicz MJ, Auperin DD and Chandy KG: Pharmacological characterization of five cloned voltage-gated $\mathrm{K}^{+}$ channels, types Kv1.1, 1.2, 1.3, 1.5 and 3.1, stably expressed in mammalian cell lines. Mol Pharmacol 45: 1227-1234, 1994.

74. McFarlane S: Attraction vs. repulsion: the growth cone decides. Biochem Cell Biol 78: 563-568, 2000.

75. Pollock NS, Atkinson-Leadbeater K, Johnston J, Larouche M, Wildering WC and McFarlane S: Voltage-gated potassium channels regulate the response of retinal growth cones to axon extension and guidance cues. Eur J Neurosci 22: 569-578, 2005.

76. Goldberg DJ and Grabham PW: Braking news: calcium in the growth cone. Neuron 22: 423-425, 1999.

77. Gomez TM and Spitzer NC: In vivo regulation of axon extension and pathfinding by growth-cone calcium transients. Nature 397: 350-355, 1999.

78. Petersen $\mathrm{OH}$ and Cancela JM: Attraction or repulsion by local $\mathrm{Ca}(2+)$ signals. Curr Biol 10: R311-R314, 2000.

79. Maruoka ND, Steele DF, Au BP, Dan P, Zhang X, Moore ED and Fedida D: alpha-actinin-2 couples to cardiac Kv1.5 channels, regulating current density and channel localization in HEK cells. FEBS Lett 473: 188-194, 2000.

80. Petrecca K, Miller DM and Shrier A: Localization and enhanced current density of the Kv4.2 potassium channel by interaction with the actin-binding protein filamin. J Neurosci 20: 8736-8744, 2000

81. Lang F, Föller M, Lang KS, Lang PA, Ritter M, Gulbins E, Vereninov A and Huber SM: Ion channels in cell proliferation and apoptotic cell death. J Membr Biol 205: 147-157, 2005.

82. Bortner CD and Cidlowski JA: Cell shrinkage and monovalent cation fluxes: role in apoptosis. Arch Biochem Biophys 462: 176-188, 2007

83. Burg ED, Remillard CV and Yuan JX: Potassium channels in the regulation of pulmonary artery smooth muscle cell proliferation and apoptosis: pharmacotherapeutic implications. Br J Pharmacol 153 (Suppl 1): S99-S111, 2008.

84. Yu SP: Regulation and critical role of potassium homeostasis in apoptosis. Prog Neurobiol 70: 363-386, 2003.

85. Yu SP, Yeh CH, Sensi SL, Gwag BJ, Canzoniero LM, Farhangrazi ZS, Ying HS, Tian M, Dugan LL and Choi DW: Mediation of neuronal apoptosis by enhancement of outward potassium current. Science 278: 114-117, 1997.

86. Bortner CD, Hughes FM Jr and Cidlowski JA: A primary role for $\mathrm{K}^{+}$and $\mathrm{Na}^{+}$efflux in the activation of apoptosis. J Biol Chem 272: 32436-32442, 1997.

87. Szabò I, Lepple-Wienhues A, Kaba KN, Zoratti M, Gulbins E and Lang F: Tyrosine kinase-dependent activation of a chloride channel in CD95-induced apoptosis in T lymphocytes. Proc Natl Acad Sci USA 95: 6169-6174, 1998.

88. Chen L, Yang P and Kijlstra A: Distribution, markers and functions of retinal microglia. Ocul Immunol Inflamm 10: 27-39, 2002.

89. Langmann T: Microglia activation in retinal degeneration. J Leukoc Biol 81: 1345-1351, 2007.

90. Schuetz E and Thanos S: Microglia-targeted pharmacotherapy in retinal neurodegenerative diseases. Curr Drug Targets 5: 619-627, 2004

91. Fordyce CB, Jagasia R, Zhu X and Schlichter LC: Microglia KV1.3 channels contribute to their ability to kill neurons. J Neurosci 25: 7139-7149, 2005

92. Chandy KG, Wulff H, Beeton C, Pennington M, Gutman GA and Cahalan MD: $\mathrm{K}^{+}$channels as targets for specific immunomodulation. Trends Pharmacol Sci 25: 280-289, 2004. 
93. Warmke JW and Ganetzky B: A family of potassium channel genes related to eag in Drosophila and mammals. Proc Nat Acad Sci USA 91: 3438-3442, 1994

94. Ludwig J, Weseloh R, Karschin C, Liu Q, Netzer R, Engeland B, Stansfeld $\mathrm{C}$ and Pongs $\mathrm{O}$ : Cloning and functional expression of rat eag2, a new member of the ether-à-go-go family of potassium channels and comparison of its distribution with that of eag1. Mol Cell Neurosci 16: 59-70, 2000.

95. Saganich MJ, Vega-Saenz de Miera E, Nadal MS, Baker H, Coetzee WA and Rudy B: Cloning of components of a novel subthreshold-activating $\mathrm{K}(+)$ channel with a unique pattern of expression in the cerebral cortex. J Neurosci 19: 10789-10802, 1999.

96. Schönherr R, Gessner G, Löber K and Heinemann SH: Functional distinction of human EAG1 and EAG2 potassium channels. FEBS Lett 514: 204-208, 2002.

97. Blatz AL and Magleby KL: Calcium-activated potassium channels. Trends in Neurosci 10: 463-467, 1987.

98. Adams PR, Constanti A, Brown DA and Clark RB: Intracellular $\mathrm{Ca}^{2+}$ activates a fast voltage-sensitive $\mathrm{K}^{+}$current in vertebrate sympathetic neurons. Nature 296: 746-749, 1982.

99. Lancaster B, Nicoll R and Perkel D: Calcium activates two types of potassium channels in rat hippocampal neurons in culture. J Neurosci 11: 23-30, 1991
100. Madison D and Nicoll R: Control of the repetitive discharge of rat CA 1 pyramidal neurones in vitro. J Physiol 354: 319-331, 1984.

101. Constanti A and Sim JA: Calcium-dependent potassium conductance in guinea-pig olfactory cortex neurones in vitro. J Physiol 387: 173-194, 1987.

102. Lancaster B and Pennefather P: Potassium currents evoked by brief depolarizations in bull-frog sympathetic ganglion cells. J Physiol 387: 519-548, 1987.

103. Schwindt PC, Spain WJ, Foehring RC, Stafstrom CE, Chubb MC and Crill WE: Multiple potassium conductances and their functions in neurons from cat sensorimotor cortex in vitro. J Neurophysiol 59: 424-449, 1988

104. Bourque CW: Transient calcium-dependent potassium current in magnocellular neurosecretory cells of the rat supraoptic nucleus. J Physiol 397: 331-347, 1988.

105. Rothe T, Jüttner R, Bähring R and Grantyn R: Ion conductances related to development of repetitive firing in mouse retinal ganglion neurons in situ. J Neurobiol 38: 191-206, 1999.

106. Wang GY, Olshausen BA and Chalupa LM: Differential effects of apamin- and charybdotoxin-sensitive $\mathrm{K}^{+}$conductances on spontaneous discharge patterns of developing retinal ganglion cells. J Neurosci 19: 2609-2618, 1999. 